"Can Bilateral Trade Agreements Help Induce Free Trade?"

Raymond Riezman

CSGR Working Paper No. 44/99

October 1999
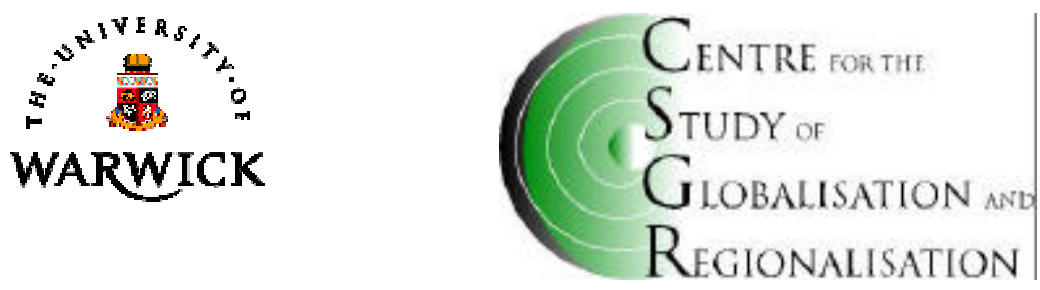


\title{
Can Bilateral Trade Agreements Help Induce Free Trade?
}

Raymond Riezman ${ }^{1}$

Department of Economics, University of Iowa.

CSGR Working Paper No. 44/99

October 1999

\begin{abstract}
:
There has been growing debate about whether bilateral trade agreements are damaging multilateral efforts to eliminate barriers to international trade. This paper develops a model in which trading blocs always charge optimal tariffs and make trade agreements based on strategic considerations. We ask a very simple question. Does the fact that trading blocs can form bilateral trade agreements make Free trade less likely to occur? The answer is that it depends on the size distribution of the trading blocs. If there is one large trading bloc along with some smaller ones then bilateral trade agreements allow the smaller trading blocs to coalesce and block the monopoly power of large trading blocs. In this case, bilateral trade agreements facilitate the attainment of free trade. Not allowing customs unions leads to more not less protection. If trading blocs are of roughly equivalent size then bilateral trade agreements allow groups of trading blocs to more effectively monopolize world trade in which case they may make free trade less likely. These results suggest that a policy that inhibits the formation of trading blocs may be harmful. We also compute the welfare effects of trade agreements to get some idea of how empirically important these issues are.
\end{abstract}

Keywords:.Free Trade Agreements, Tariffs, Welfare, General Equilibrium.

Address for correspondence:

Ray Riezman,

Department of Economics,

University of Iowa,

Iowa City, IA 52242, USA

e-mail: raymond-riezman@uiowa.edu

\footnotetext{
${ }^{1}$ I would like to thank M. Ayhan Kose for his invaluable research assistance. Carsten Kowalczyk has provided valuable suggestions. Also Carl Davidson, Richard Boylan and seminar participants at the Midwest International Economics Group meeting and Georgetown Uniersity provided useful comments on an earlier draft.
} 


\section{Introduction ${ }^{1}$}

The new spate of regional trading arrangements, such as NAFTA, have led to renewed interest in one of the oldest questions in the customs unions literature: ${ }^{2}$ namely, are Regional Trading Agreements a help or a hindrance in the goal of attaining free international trade? In the current literature there is a vigorous debate taking place about this basic issue. While some researchers claim that these agreements can be instrumental in attaining global free trade, others fiercely oppose regional agreements, since they see them as a potential threat to the multilateral trading system. ${ }^{3}$

In this paper, we examine this issue using a simple general equilibrium model. In particular, we address the following questions: are regional trade agreements stepping stones to global free trade? Or, should they be seen as a threat to the multilateral trading system, and, therefore, be banned? To understand the implications of various policies, we compare equilibrium outcomes when bilateral agreements are allowed and when they are not allowed. The most surprising result of this investigation is that not allowing bilateral agreements can result in more protection and lower world welfare. Whether the ban on bilateral agreements helps or not depends on the size distribution of trading blocs.

There has been a growing body of literature which examines several effects of increasing regionalism on free trade: Krugman (1991), using a monopolistically competitive model, shows that regional trade agreements can potentially increase external tariffs due to the non-cooperative behavior of large trading blocs. An important outcome of his analysis is that if there are only three trading blocs, the world welfare is at its minimum. However, subsequent studies show that his

\footnotetext{
${ }^{1}$ I would like to thank M. Ayhan Kose for his invaluable research assistance. Carsten Kowalczyk has provided valuable suggestions. Also, Carl Davidson, Richard Boylan and seminar participants at the Midwest International Economics Group meeting and Georgetown University provided useful comments on an earlier draft.

${ }^{2}$ The previous version of the question was "are customs unions stepping stones to free international trade?" This question finds its roots in the work of Viner (1950) and Lipsey (1970). Also, Arndt (1969), while presenting a general discussion of customs union tariff policy, notes that " $\ldots$ the existence of the European Economic Community facilitated the Kennedy round." See Sampson (1996) for more information about the recent increase in the number of free trade agreements.

${ }^{3}$ On one side we have Bhagwati (1995) who argues that, "...further expansion and creation of free trade areas, instead of concentration now on multilateralism at the WTO, is a mistake." Summers (1991) on the other side of the debate argues that, "...holding the degree of multilateral progress constant, the world will be better off with more regional liberalization."
} 
results are sensitive to some of his assumptions. ${ }^{4}$ Bhagwati and Panagariya (1996) conclude that preferential trade agreements are mostly welfare reducing since the partner countries might end up with severe welfare losses due to substantial amount of trade diversion. Krueger (1996), employing Vinerian arguments, finds that Free Trade Areas constitute a potential threat to the world trading system because these types of agreements are, in general, trade diverting and they lead to formation of new interest groups who oppose the multilateral tariff reductions.

Interestingly, some researchers paint a completely different picture about the implications of bilateral trade agreements: Nordstrom (1995) finds that regional trade agreements might provide trading blocs with stronger incentives to pursue multilateral trade liberalization since establishing these types of agreements allows small countries to more effectively deal with large trading blocs. Perroni and Whalley (1996) indicate that recent regional trade agreements generally take the form of Free Trade Associations in which member countries can choose their external tariff rates freely. In contrast to Krugman's findings, this new form of regionalism does not increase the monopoly power of newly established trading blocs and does not necessarily imply higher external trade barriers between the emerging trading blocs. They conclude that increasing regionalism is not a threat to the multilateral trading system. Campa and Sorenson (1996) also employ Krugman's framework, but they consider an infinitely repeated tariff setting game. Their results suggest that global free trade equilibrium can be sustainable if the small economies form a trading bloc since the integration of small countries can undermine the market power of the larger trading blocs.

Our approach to the questions posed above differs in some key ways from others in this literature: First, we analyze the strategic interactions between trading blocs in a general equilibrium model. In this model, tariffs are determined endogenously implying that trading blocs are individually rational. Second, we investigate the implications of policy proposals to ban bilateral trade agreements in an environment where trading blocs optimally respond to externally imposed policies by evaluating costs and benefits of a menu of free trade agreements. In other

\footnotetext{
${ }^{4}$ Frankel, Stein and Wei (1996) find that the magnitude of transportation costs is an important determinant of the desirability of Regional Trade Agreements. By introducing transport costs in an extended version of Krugman's model, they show that Free Trade Agreements result in welfare losses, if transport costs are not very high. Deardorff and Stern (1994) relax the Krugman's assumption of imperfect substitutes and find that world welfare rises as the world moves from autarky to free trade in the context of a Ricardian trade model. See also Bagwell and
} 
words, trading blocs optimize at all stages both in terms of who they cooperate with and what tariffs they charge given the constraints imposed by their cooperative agreements. We model the decision to cooperate and under what terms cooperation will take place. Third, we analyze Free Trade Associations (FTAs) and Customs Unions (CUs) and document various implications of these different types of agreements. Although a significant fraction of recent trade arrangements has taken the form of FTAs, the massive body of literature sparked by the Krugman's study has largely ignored FTAs, and exclusively focused on the implications of CUs. ${ }^{5}$ Fourth, we calculate welfare gains associated with these agreements for each trading bloc and the world.

To sharpen the issue of whether bilateral agreements are a help or a hindrance to the attainment of free trade we consider two different types of policies one could potentially use to limit Regional Trading Agreements. ${ }^{6}$ The first would ban all bilateral trade agreements. A weaker version would ban customs unions but allow Free Trade Associations. We calibrate our model to simulate two different world economies. Then we conduct policy experiments on both economies. In the first economy, when bilateral agreements are allowed free trade is the unique equilibrium. Banning bilateral agreements results in the non-cooperative tariff equilibrium being the outcome. Thus, in this case bilateral agreements play an essential role in the attainment of free trade. However, in the second economy, the reverse is true. A customs union is the equilibrium when bilateral agreements are allowed, but free trade is chosen when they are banned. In this case, bilateral agreements do obstruct free trade.

The intuition for these results is clear. Bilateral agreements allow trading blocs to merge and essentially get larger for the purposes of trade policy. In the first economy two smaller trading blocs use the threat of a customs union to block the third larger trading bloc from using tariffs. In equilibrium, this threat is not carried out and free trade is the result. In the second economy, what happens is that the initial endowment structure is such that in equilibrium two trading blocs get together and exploit the third, hence blocking free trade. Hence, allowing trading blocs does have the potential to block free trade, but it also has the potential to allow smaller

Staiger (1993a, 1993b) who study the interactions between the formation of FTAs and CUs and multilateral trade liberization.

${ }^{5}$ The WTO (1995) reports that "most notifications made to GATT have involved free trade areas, and the number of customs union agreements is small." 
blocs to successfully oppose larger ones and in some cases can actually facilitate the attainment of free trade. This suggests that any proposed policy to ban or limit bilateral agreements should be structured to take account of these potential effects.

\section{The Model}

We first construct a model sufficiently general to incorporate an arbitrary number of trading blocs. There are $\mathrm{N}$ trading blocs in our model. Within the trading blocs, member countries freely trade with each other. Trading blocs set tariffs optimally and consider all possible trade agreements when they decide what to do. They can choose not to be part of any trade agreement and charge the optimal tariff or they could decide to join a coalition with other trading blocs. They could be part of an FTA, a CU or an N trading bloc coalition-free trade. In the FTA member trading blocs agree to free trade between themselves but are allowed to set their external tariffs independently. A customs union is an FTA with the additional provision that the external tariff is set jointly by the members. A CU (or FTA) of all trading blocs is, of course, Free trade.

Trading blocs play a two-stage game. In the second stage, tariffs are chosen, given the coalition structure. Trading blocs or coalitions of trading blocs choose tariffs optimally yielding a Nash equilibrium in tariffs. ${ }^{7}$ In the first stage, trading blocs use information from the second stage to choose which coalition, if any, to join. In order to determine the outcome of the first stage we employ the core solution concept. ${ }^{8}$ The core is a natural concept to use because it selects allocations that cannot be blocked by any potential group of trading blocs. As we shall see the potential to threaten to form coalitions will have important effects.

\section{II.1. The Environment}

Think of a world of $\mathrm{N}$ trading blocs. Each trading bloc is endowed with a fixed amount of each final commodity. ${ }^{9}$ Let $Y_{j}^{i}$ be trading bloc i's endowment of good j. For simplicity, there is

\footnotetext{
${ }^{6}$ Bhagwati and Panagariya (1996) ask “....should these proposals for proliferating PTAs, especially when inclusive of hegemonic powers such as the United States, be encouraged by economists?" We take the question one step further and ask whether banning bilateral trade agreements would help attain free trade.

${ }^{7}$ We specify later how coalitions of trading blocs determine their optimal tariff.

${ }^{8}$ See Riezman (1985) for a complete discussion of the first stage solution.

${ }^{9}$ It would be more general if we endow trading blocs with factors of production, but it would increase the complexity of the model and would not change the basic results.
} 
one unit of each good in the world. If $Y_{j}^{i}=.6$ it means trading bloc $\mathrm{i}$ is endowed with $60 \%$ of the world's endowment of good j.

In each trading bloc, the agents derive utility by consuming $\mathrm{M}$ different goods. Assume that each trading bloc consists of individuals with identical Cobb-Douglas preferences. Then the utility function of a representative agent is the same as the aggregate and is given by

$$
U^{i}=\sum_{j=1}^{M} \beta_{j}^{i} \ln X_{j}^{i}
$$

where $U^{\mathrm{i}}$ is the utility of trading bloc $\mathrm{i}, \beta_{j}^{i}$ is the weight trading bloc $\mathrm{i}$ puts on commodity $\mathrm{j}$, and $X_{j}^{i}$ is the aggregate consumption of good $\mathrm{j}$ in trading bloc $\mathrm{i}$.

The volume of trade $Z_{j}^{i}$, is defined to be $Z_{j}^{i}=X_{j}^{i}-Y_{j}^{i}$. Positive values of $Z_{j}^{i}$ indicate imports, negative values exports. Trading blocs charge optimal tariffs on imports. Denote the ad valorem tariff charged by trading bloc $\mathrm{i}$ on imports of good $\mathrm{j}$ by $t_{j}^{i}$. Then if the world price for $\operatorname{good} \mathrm{j}$ is $P_{j}$, then the domestic price of good $\mathrm{j}$ in trading bloc i is $P_{j}^{i}=\left(1+t_{j}^{i}\right) P_{j}$.

Given that each trading bloc consists of identical individuals aggregate demand is obtained from maximizing utility subject to the budget constraint

$$
\sum_{j=1}^{M} P_{j}\left(1+t_{j}^{i}\right) X_{j}^{i}=I^{i}=\sum_{j=1}^{M} P_{j}\left(1+t_{j}^{i}\right) Y_{j}^{i}+P_{j} t_{j}^{i} Z_{j}^{i} \quad i=1,2, \ldots, N
$$

where $I^{i}$ is income in trading bloc $\mathrm{i}$ and consists of income from the endowment plus tariff revenue. 10

\section{II.2. The Equilibrium}

The trading blocs solve their optimization problems by maximizing (1) subject to (2). At the equilibrium, the aggregate expenditure in each trading bloc must equal the value of the endowment vector. In other words, the resource constraint of each trading bloc $\mathrm{i}$ is given by

$$
\sum_{j=1}^{M} P_{j} X_{j}^{i}=\sum_{j=1}^{M} P_{j} Y_{j}^{i}
$$

\footnotetext{
${ }^{10} \mathrm{We}$ assume that tariff revenue is rebated to consumers lump sum.
} 
In addition to this constraint, the world demand for each good, which is normalized to one, should be equal to world supply:

$$
\sum_{i=1}^{N} X_{j}^{i}=\sum_{i=1}^{N} Y_{j}^{i}=1
$$

These two conditions imply that world expenditure on each good will equal the world price for that good.

\section{II.3. The Numerical Solution Method}

Because we cannot solve the model analytically we use a recursive numerical solution method to find an approximate solution for equilibrium allocations, prices and tariffs. In order to utilize the solution algorithm, we specify the number of trading blocs, the number of goods and endowment of each trading bloc. We assume that $\mathrm{M}=\mathrm{N}=3$ and $\beta_{j}^{i}=1 / 3$ for all $\mathrm{i}, \mathrm{j}=1,2,3$. Assuming $\mathrm{N}=3$ has a natural interpretation since many authors have discussed the possibility that the world is rapidly moving towards three trading blocs (see for example, Frankel, Stein and Wei (1996).) Any variation in cross trading bloc preferences or preferences across commodities could be replicated by a suitable adjustment of endowments. Thus, we focus on variation in the endowment matrix, but the results can apply to more general situations.

The intuition of our solution method is simple: for a given endowment matrix, we can compute the equilibrium with optimal tariffs. Thus, when a trading bloc considers changing its tariff it has to make this calculation for any proposed tariff change. Once a trading bloc changes its tariff we have to re-compute optimal tariffs for the other two trading blocs. This continues until no trading bloc wants to alter its tariff rate. ${ }^{11}$

We structure our simulations in such a way that in all the possible equilibria each trading bloc exports one good (trading bloc i exports good i) and import the other two goods. Transfer payments between trading blocs are not allowed. Kowalczyk and Sjostrom (1994) analyze a model of customs unions in which side payments are allowed, but their framework requires that there are no spillovers to non-members when a customs union forms. They find that the use of inter-bloc transfers can facilitate the attainment of free trade.

\footnotetext{
${ }^{11}$ For details of this solution method, see Kennan and Riezman (1990).
} 
Operationally, FTAs and CUs put constraints on the feasible tariff matrix. For an FTA, tariffs between the member blocs are set to zero, and external tariffs are set independently ${ }^{12}$. This means to compute the equilibrium, the appropriate tariffs are constrained to be zero and optimal tariffs are computed as before. Alternatively, one might consider a more general case in which we let coalitions have tariffs between the member blocs. We require that free trade be practiced within the coalition. Computing customs unions equilibria is a bit more complicated. One can think of a CU as an FTA with the added feature that the external tariff is set jointly. In general, (except when the endowment pattern is symmetric) there will be a conflict of interest between the member trading blocs as to what the external tariff should be.

How potential customs union members resolve this conflict is a serious problem deserving of careful analysis. In fact, there is at least one paper which addresses this issue directly (see Gatsios and Karp (1991).) In their model, members sometimes have congruent interests and sometimes opposing interests. Here member's interests are always opposed in the sense that if their endowment structure is not symmetric they want different external tariffs. There is no simple or obvious solution to this problem. We assume that trading blocs compromise on the external tariff by splitting the utility difference. Operationally, we calculate the equilibrium by computing two equilibria for each potential customs union. In one equilibrium one trading bloc picks the external tariff for the customs union. In the other equilibrium the other trading bloc chooses the external tariff. We then average the utilities for each trading bloc between the two equilibria. We assume then that the customs union selects an external tariff that gives each trading bloc this average utility.

\section{Coalition Choice}

In this section we model the choice of coalition partners. Trading blocs use the results from the previous section to decide which coalition, if any, to join. How trading blocs make this decision is modeled by the choice of a cooperative solution concept. The particular solution concept we use is the core. This was first used in Riezman (1985) to analyze the formation of customs unions and seems to be a natural one to use for this problem. One difference from Riezman (1985) is that we broaden the scope to include FTAs as well CUs.

\footnotetext{
${ }^{12}$ As shown by Richardson (1993) there is a problem if two FTA members try and sustain different tariff rates on the same good. Even if rules of origin are strictly enforced it still may not be possible to sustain different tariff
} 
With three trading blocs there are eight possible configurations for world trading arrangements. There could be no bilateral trade agreement with each trading bloc charging optimal tariffs. Call this coalition structure 1 denoted by $\{\{1\},\{2\},\{3\}\}$. This is the noncooperative Nash equilibrium. There are, in addition, three possible customs unions, and potentially three free trade associations. Finally, we could have the grand coalition form, coalition structure 8 , and get free trade. These coalition structures are summarized in Table 1:

\section{[insert Table 1 here]}

The notation is meant to suggest that in Free Trade Associations, members have free trade amongst themselves, but select tariffs to the outside trading bloc independently. For example, in NAFTA, the US and Mexico have free trade, but are free to set tariffs to third parties independently. In the case of a customs union, the external tariff is jointly determined. When two trading blocs import the same good they internalize the tariff externality that exists in a customs union.

To define the core we need some preliminary definitions. Let $\mathrm{A}_{\mathrm{j}}$ be the allocation of consumption goods when coalition structure $\mathrm{j}$ is chosen. For example, $\mathrm{A}_{4}$ is the matrix of consumption good allocations that prevails when there is an FTA between trading blocs 1 and 2 . Each trading bloc's utility can be expressed as a function of an allocation. $\mathrm{U}^{\mathrm{i}}\left(\mathrm{A}_{\mathrm{j}}\right)$ is the utility of trading bloc $\mathrm{i}$ when allocation $\mathrm{A}_{\mathrm{j}}$ is realized. $\mathrm{U}^{3}\left(\mathrm{~A}_{4}\right)$, for example, is the utility trading bloc 3 receives when 1 and 2 form an FTA.

The first issue to clarify is how trading blocs evaluate membership in a particular coalition. When a trading bloc evaluates membership in a two or three trading bloc coalition, it is straightforward. In these cases there is only one allocation which could occur so trading blocs simply compute their utility under the relevant allocation. For example, Trading bloc 1 will get a utility of $U^{1}\left(A_{6}\right)$ if it joins in a customs union with trading bloc 3, i.e. $U^{1}(\{1,3\})=U^{1}\left(A_{6}\right)$. Or trading bloc 2 gets $U^{2}\left(A_{8}\right)$ if free trade occurs, $U^{2}(\{1,2,3\})=U^{2}\left(A_{8}\right)$.

How a trading bloc evaluates not being in a coalition is problematic. A trading bloc knows that if they do not join a coalition any of three allocations could occur; the other two blocs

rates. However, for the purposes here we ignore this complication. 
could form an FTA, a CU or Nash equilibrium (allocation 1) could occur. In trying to predict what will happen if it does not join a coalition the trading bloc assumes that the other countries will choose the best alternative for them. In cases where the best alternative is not unique trading blocs adopt a pessimistic view and assume they will receive the lowest payoff of the remaining possible allocations. For each model economy and each policy experiment we check to see that the assumptions made by individual coalitions are consistent with the equilibrium outcomes. This way of handling this problem makes sense because chances are the other two trading blocs will make a coalition choice that is best for them. This usually means that the excluded trading bloc suffers lower utility. We now turn to defining the core.

To define the core we need to first define blocking.

Definition: A coalition $\mathrm{S}$ blocs allocation $\mathrm{j}$ if for all trading blocs $\mathrm{i}$ in $\mathrm{S}$

$$
\mathrm{U}^{\mathrm{i}}(\mathrm{S}) \geq \mathrm{U}^{\mathrm{i}}\left(\mathrm{A}_{\mathrm{j}}\right)
$$

with strict inequality for at least one member of S.

We can now define the core.

Definition: An allocation $A_{j}$ is in the core if it is unbloced by any feasible coalition.

Allocations in the core are stable in the sense that no trading bloc does better in a feasible coalition. It implies that trading blocs can communicate with each other about possible trading arrangements, but all decisions to join coalitions are voluntary. In addition, no trading bloc can prevent other trading blocs from forming coalitions.

The core has a natural interpretation in this setting. Allocations in the core will be the ones observed. In the case of multiple core allocations the theory offers no guidance as to which ones might actually be observed. Likewise, if the core is empty the model makes no prediction as to what might happen. In the next section of the paper we use the core equilibrium concept to investigate policies that limit coalitional choices.

\section{Do Bilateral Agreements Make Free Trade Less Likely?}

To answer this question we perform two simple policy experiments. One policy experiment bans all types of bilateral agreements. In the model of the world economy presented here it simply means that free trade or Nash equilibrium are the only possible allocations. All customs unions and free trade associations are banned. The outcome under this regime can then 
be compared to the outcome when Article XXIV-type (customs unions and free trade associations) are allowed. We consider a second, less drastic policy which forbids customs unions, but allows free trade associations. The rationale for this policy is that it keeps the tariff reduction aspects of bilateral agreements, while not allowing the tariff coordination aspect.

\section{IV.1. Economy 1}

We simulate two different world economies which differ by their endowment pattern. In the first economy (see Table 2) there is one large trading bloc (43\% of the world's endowment evaluated at free trade prices) and two smaller ones (each has about $28 \%$ of the total world endowment.) First, consider what happens if there are no restrictions on bilateral agreements. The CU $\{2,3\}$ blocs NE and FTA $\{2,3\}$. FTA $\{1,2\}$ and FTA $\{1,3\}$ block each other because the non-member can always join with one of the members and make all members of the new coalition at least as well off and one member strictly better off. For the same reasons CU $\{1,2\}$ and CU $\{1,3\}$ block each other. The customs union between 2 and 3 is blocked by $\mathrm{CU}\{1,2\}$. A single trading bloc coalition of trading bloc 1 does not block FT because $\mathrm{U}^{1}(\{1\})=112.626$, trading bloc 1 can only guarantee itself a utility level of 112.626 by charging tariffs and refusing to join

any trade agreements. ${ }^{13}$ Clearly single trading bloc coalitions with 2 or 3 do not block free trade. Thus free trade is unblocked and the only allocation in the core.

\section{[insert Table 2 here]}

What happens in this economy is that trading bloc 1 can win a tariff war, its utility is higher at Nash equilibrium than at free trade. However, the threat of blocs 2 and 3 to form a customs union is sufficient to keep trading bloc 1 from charging tariffs in equilibrium and the result is free trade. We next evaluate what happens if trade agreements are restricted.

\section{IV.1a. All bilateral agreements banned}

Suppose all CUs and all FTAs are banned. The NE and FT are the only possible equilibria. In this case $\mathrm{U}^{1}(\{1\})=117.360$. Thus, if trading bloc 1 charges tariffs it guarantees

\footnotetext{
${ }^{13}$ Here trading bloc 1 assumes that if it plays alone then 2 and 3 will form a customs union because that gives them the highest payoff conditional on 1 charging tariffs and refusing to join a coalition.
} 
itself a utility level of 117.360 which is higher than its free trade level. Thus, NE will block FT and will be the only core allocation. In this economy banning bilateral trading agreements results in higher tariffs and lower welfare for the two small trading blocs but the large bloc benefits. In this economy trade agreements allow smaller trading blocs to effectively oppose large ones by threatening to form a customs union. This threat essentially prevents the large trading bloc from charging tariffs and refusing to cooperate with other trading blocs. The result is that free trade is the unique equilibrium. The result is subtle in the sense that for this economy bilateral agreements are not observed, yet they play an instrumental role. The option they provide to smaller trading blocs leads to a more equitable and efficient outcome.

\section{IV.1b. Customs unions banned}

We next consider a more moderate policy which allows FTAs but bans CUs. In this economy $\mathrm{U}^{1}(\{1\})=117.707^{14}$ so coalition $\{1\}$ blocs FT and FTA $\{1,2\}$. FTA $\{2,3\}$ blocks NE since 2 and 3 do better in the FTA. $U^{2}\{2\}=U^{3}\{3\}=67.115$ so FTA $\{2,3\}$ is unblocked and the unique equilibrium. Again, banning trade agreements leads to more not less protection. Again, the large trading bloc (1) benefits from this restriction, while the two smaller ones suffer. This more moderate policy is better for all trading blocs than the complete ban. However, this policy still results in efficiency losses when compared to the situation in which all bilateral agreements are permitted.

In economy 1 , the possibility that trading blocs can form customs unions and free trade associations results in free trade being the only allocation in the core. When CUs and FTAs are not allowed then Nash equilibrium is the only core allocation. If only CUs are banned then 2 and 3 will form an FTA. In both cases, restricting bilateral agreements benefits the large trading bloc at the expense of the two smaller ones. The intuition for these results is that customs unions, and to a lesser extent free trade areas, allow smaller trading blocs to essentially become bigger for the purposes of making trade policy. This allows them to compete more effectively against big trading blocs. This more equal footing can result in free trade being chosen in equilibrium. Thus, the lesson learned from economy 1 is that bilateral agreements can facilitate the attainment of free

\footnotetext{
${ }^{14}$ Now trading bloc 1 assumes that if it plays alone 2 and 3 will form an FTA because they both do better than at NE.
} 
trade. Banning such agreements could have the opposite effect that those pushing such policies desire.

\section{IV.2. Economy 2}

In the second economy, the size distribution of trading blocs is more even. There is one small trading bloc with $30 \%$ of the world's endowment and two larger blocs with $35 \%$ each.

\section{[insert Table 3 here]}

When bilateral agreements are permitted trading blocs 2 and 3 will form a customs union. The CU $\{2,3\}$ blocks FT, NE, FTA $\{2,3\}$, FTA $\{1,2\}$ and CU $\{1,2\}$ because in all cases trading blocs 2 and 3 do better in a customs union with each other than in any of the other equilibria. None of the other allocations can block $\mathrm{CU}\{2,3\}$. Thus, $\mathrm{CU}\{2,3\}$ is the unique core allocation.

\section{IV.2a. All bilateral agreements banned}

When all bilateral agreements are banned free trade is the unique equilibrium. In this case FT and $\mathrm{NE}$ are the only possible equilibria. FT blocks NE since every trading bloc is strictly better off at free trade. Obviously, NE does not block FT thus FT is the unique core allocation. This result is the opposite of economy 1. Here, allowing bilateral trade agreements prevents free trade from occurring. In other words, customs unions are not a stepping stone to free trade. Intuitively, what happens is that in economy 2 the trading blocs are of similar size. When the two biggest form a customs union they can win a tariff war with the third trading bloc. It turns out that the small trading bloc cannot do well enough in a customs union with one of the large trading blocs to block the customs union between the two larger trading blocs. In this case, bilateral agreements are bad in that they allow the two larger trading blocs to become big enough that they can use their size to exploit the smaller trading bloc. ${ }^{15}$

\section{IV.2b. Customs unions banned}

When only FTAs are allowed, free trade blocks all other allocations and is the unique equilibrium. So, in this case allowing FTAs has no effect on the outcome and is harmless. So, for economy 2 allowing CUs can lead to inefficiency. FTAs are benign however. 


\section{IV.3. Policy Implications}

The results of this section suggest caution when considering banning bilateral trade agreements. Economy 1 illustrates the point that customs unions can allow smaller trading blocs to more effectively compete with large ones. What is interesting is that this more effective competition results in free trade. Banning customs unions in this case would have the opposite effect that proponents of such a policy intend.

One might ask is the world more like economy 1 or economy 2? While we acknowledge that there are more than three trading blocs in the world today many have suggested that the world is headed in that direction (see Frankel, Stein, and Wei (1996).) Suppose the world does evolve in that direction. Can we say anything about which economy is the most plausible representation of that world. In Table 4, we present the results of some preliminary calculations that suggest that economy 1 may, in fact, be close to what we would have.

\section{[insert Table 4 here]}

We divide the world into three regions and use 1992 data to compute the aggregates for these three regions. We then normalize these endowments so that the endowment of each commodity adds to one. Following this procedure we can make the endowment matrix look exactly like the endowment matrix of economy 1 . This is a very crude calculation, but the point is that the endowment structure of economy 1 is not implausible should the world evolve into three trading blocs. This reinforces our cautionary statements above. Banning bilateral trade agreements could backfire leading to more not less protection.

\section{Welfare Implications of Trade Agreements}

We use utility comparisons to determine equilibrium in previous sections. In some cases the differences in utility are quite small. Also, the utility function is an ordinal index. This raises questions about the empirical importance of our earlier results. In this section, we calculate the welfare costs associated with bilateral trade agreements to get a feel for how large these costs are.

\footnotetext{
15 This result is consistent with the conclusions of Summers (1991) and Nordstrom (1995). In particular, Summers notes that "...the essential reason for concern is that large trading blocs will have more monopoly power than small
} 
In other words, we would like to answer the following question: how much would trading blocs lose if they established various forms of bilateral free trade agreements instead of a world of free trade $?^{16}$ Generally, we find that the welfare losses associated with the absence of free trade are quite large.

The measure of the welfare cost we use is the fraction $\delta$ by which the consumption allocations should be decreased in the free trade equilibrium to keep the representative agent with the same utility as the one in an equilibrium with tariffs. We use the measure of Compensating Variation in Consumption to evaluate the welfare costs associated bilateral agreements. ${ }^{17}$ The welfare $\operatorname{cost} \delta$ is calculated as

$$
\begin{aligned}
& U^{T}\left(x_{1}, x_{2}, x_{3}\right)=U^{F}\left((1-\delta) x_{1},(1-\delta) x_{2},(1-\delta) x_{3}\right) \\
& U^{T}: \text { utility under an equilibrium with positive tariffs } \\
& U^{F}: \text { utility under free trade equlibrium }
\end{aligned}
$$

Tables 5 and 6 present the welfare costs associated with economies 1 and 2 . Since the measure of welfare cost is in terms of consumption, it provides an estimate of the percentage reduction in aggregate consumption as a result of establishing bilateral trade agreements instead of having a world of free trade. To illustrate, consider the welfare costs associated with the Nash equilibrium in Table 5. The first trading bloc has 0.99 percent consumption gain when its consumption is compared with the one in free trade equilibrium. However, the second and third trading blocs face a severe decline in their consumption. Each of these trading blocs consumes approximately 6.5 percent less in a world of three trading blocs charging optimal tariffs than a world of free trade.

\section{[Tables 5 and 6 here]}

Table 5 indicates that the welfare losses associated with banning bilateral agreements are quite large. Recall that banning such agreements in the case of economy 1 means that we have

\footnotetext{
ones and then will use it."

${ }^{16}$ Welfare implications of free trade agreements, particularly regional trade agreements, have been a hotly debated issue in recent years. A number of recent studies document that current form of regional trade agreements can potentially result in significant welfare losses. See Perroni and Whalley (1994) and Krugman (1991).

17 This measure is slightly different than the Equivalent Income Variation measure which basically looks at the change in income at constant prices. The measure of compensating variation in consumption is widely used in macroeconomics and finance literature to evaluate the costs of business cycles and international risk sharing. See Lucas (1987), Cole and Obstfeld (1991) for the use of this measure in different contexts.
} 
Nash equilibrium rather than free trade. In this case, trading bloc 1 gains a small amount, slightly less than 1 percent of consumption, while the other smaller trading blocs experience a loss of more than 6 percent. The losses are quite large as compared to the gains as the world welfare loss of more than 3 percent indicates. ${ }^{18}$ Some of the other results are interesting. Notice that in terms of world welfare losses, $\mathrm{CU}\{2,3\}$ has a higher aggregate welfare loss than NE. This suggests that the resulting tariff war between trading bloc 1 and the $\mathrm{CU}\{2,3\}$ causes more distortion than the tariff war when each trading bloc makes policy independently.

Also interesting is that the welfare losses for trade agreements between the large bloc and one of the small blocs $(\{1,2\}$ or $\{1,3\})$ are small relative to the effect of the two smaller blocs joining forces. The intuition here is that when the two small blocs get together the resulting tariff war is between two roughly comparable size blocs. This leads to much higher tariffs and welfare losses than when a large and small bloc get together to oppose a small bloc.

The welfare losses for economy 2 (in Table 6) tend to be smaller. Again, keeping with the previous intuition since all blocs in this economy are close to the same size, any trade agreement results in a tariff war between two blocs of quite different size. This leads to smaller tariffs and lower welfare losses.

\section{Concluding Comments}

We have shown that banning bilateral trade agreements can lead to more, not less protection. In the case where this is true the potential welfare losses are quite large. We also showed that bilateral agreements can lead to more protection. This occurs when trading blocs are initially approximately the same size. However, the welfare losses associated with these trade agreements tend to be small. The policy implication is that banning trade agreements is a very risky policy. Even if at the initial conditions banning agreements proved to be useful, there is no guarantee that the world will not evolve into a situation in which such bans are harmful.

Which situation actually prevails today is an empirical question. Preliminary calculations suggest that economy 1 (where banning agreements is harmful) is a plausible possibility.

\footnotetext{
${ }^{18}$ To compute world welfare cost we simply aggregate the welfare costs of the individual trading blocs. Referring to Table 5 you would have to increase the aggregate endowment of the world by $3.377 \%$ to have each trading bloc as well off at Nash equilibrium as they are at free trade.
} 
The welfare calculations we performed suggest some interesting possibilities. What happens in our model economies is that when trade agreements lead to trading blocs of equal size they tend to be welfare enhancing. If they lead to blocs of unequal size then the opposite occurs. More careful work needs to be done to determine the robustness of these results. 


\section{References:}

Arndt, S., 1969, Customs unions and the theory of tariffs, American Economic Review 59, 108118.

Bagwell, K., and R. W. Staiger, 1993a, Multilateral tariff cooperation during the formation of regional free trade areas, NBER Working paper No: 4363

Bagwell, K., and R. W. Staiger, 1993b, Multilateral tariff cooperation during the formation of customs unions, NBER Working paper No: 4543

Bhagwati J., 1995, U.S. trade policy: The infatuation with free trade areas, in J. Bhagwati and A. O. Krueger (eds.), The dangerous drift to preferential trade agreements, The AEI Press, Washington D.C., 1-18.

Bhagwati, J. and A. Panagariya, 1996, Preferential trading areas and multilateralism: strangers, friends or foes?, in Free Trade Areas or Free Trade? The Economics of Preferential Trading Agreements in J. Bhagwati and A. Panagariya (eds.), AEI press, forthcoming.

Bond, E. and C. Syropoulos, 1996, The size of trading blocs: Market power and world welfare effects, Journal of International Economics, 40, 1/2, 411-437.

Campa, J. M., and T. L. Sorenson, 1996, Are trade blocs conducive to free trade?, Scandinavian Journal of Economics 98, 263-273.

Cole, H.L. and M. Obstfeld, 1991, Commodity Trade and International Risk Sharing: How much do Financial Markets Matter?, Journal of Monetary Economics 28,3-24.

Deardorff, A. V., and R. M. Stern, 1994, Multilateral trade negotiations and preferential trading arrangements, in A. V. Deardorff and R. M. Stern (eds.), Analytical and Negotiating Issues in the Global Trading System, University of Michigan Press, 27-94.

Frankel, J. A., E. Stein, and S. J. Wei, 1996, Regional trading agreements: natural or supernatural?, American Economic Review 86, 52-56.

Gatsios, K., and L. Karp, 1991, Delegation games in customs unions, Review of Economic Studies 58, 391-397.

Haveman, J., 1993, Some welfare effects of dynamic customs union formation, mimeo, Purdue University.

Kennan, J., and R. Riezman, 1990, Optimal tariff equilibria with customs unions, Canadian Journal of Economics 90, 70-83.

Kowalczyk, C. and T. Sjostrom, 1994, Bringing GATT into the core, Economica, 61, 301-317. 
Kowalczyk, C, 1990, Welfare and customs unions, NBER WP \#3476.

Krueger, A. O., 1995, Free trade agreements versus customs unions, NBER WP\#5084

Krugman, P., 1991, Is bilateralism bad?, in E. Helpman and A. Razin, eds., International Trade and Trade Policy, Cambridge, MIT Press

Lipsey, R. G., 1970, The theory of customs unions: A general equilibrium analysis, Weidenfeld and Nicholson, London.

Lucas, R.E., 1987, Models of Business Cycles, Oxford, Blackwell

Markusen, J. R., and R. M. Wigle, 1989, Nash equilibrium tariffs for the United States and Canada: The roles of country size, scale economies, and capital mobility, Journal of Political Economy 97, 368-386.

Nordstrom, H., 1995, Customs unions, regional trading blocs and welfare, in R. Baldwin, P. Haaparanta, and J. Kiander (eds.), Expanding membership of the European Union, Cambridge University Press, 54-78.

Perroni, C. and J. Whalley, 1994, The new regionalism: trade liberalization or insurance?, NBER WP\#4626

Perroni, C. and J. Whalley, 1996, How severe is global retaliation risk under increasing regionalism?, American Economic Review 86, 57-61.

Richardson, M., 1993, Endogenous protection and trade diversion, Journal of International Economics 34, 309-324.

Riezman, R., 1985, Customs unions and the core, Journal of International Economics 19, 355365 .

Sampson, G. P., 1996, Compatibility of regional and multilateral trading arrangements: reforming the WTO process, American Economic Review 86, 88-82.

Summers, L., 1991, Regionalism and the world trading system, in Federal Reserve Bank of Kansas City, Policy implications of trade and currency zones., 295-301.

Summers, R., and A. Heston, 1991, The Penn World Table (Mark 5): An Expanded Set of International Comparisons, 1950-1988, Quarterly Journal of Economics 106, 327-368.

Viner, J., 1950, The customs union issue, Carnegie Endowment for International Peace.

World Trade Organization, 1995, Regionalism and the world trading system, WTO, Geneva. 


\begin{tabular}{cc}
\hline \hline & \multicolumn{1}{c}{ Table 1 } \\
& Coalition Structures \\
\hline $\begin{array}{c}\text { Coalition } \\
\text { Number }\end{array}$ & \multicolumn{1}{c}{ Coalition } \\
Structure \\
\hline 1. & $\{1\}\{2\}\{3\}$ Nash Equilibrium \\
2. & $\{1\}\{\{2\},\{3\}\}$ FTA between 2 and 3 \\
3. & $\{2\}\{\{1\},\{3\}\}$ FTA between 1 and 3 \\
4. & $\{3\}\{\{1\},\{2\}\}$ FTA between 1 and 2 \\
5. & $\{1\}\{2,3\}$ CU between 2 and 3 \\
6. & $\{2\}\{1,3\}$ CU between 1 and 3 \\
7. & $\{3\}\{1,2$,$\} CU between 1$ and 2 \\
8. & $\{1,2,3\}$ Free Trade \\
\hline \hline
\end{tabular}




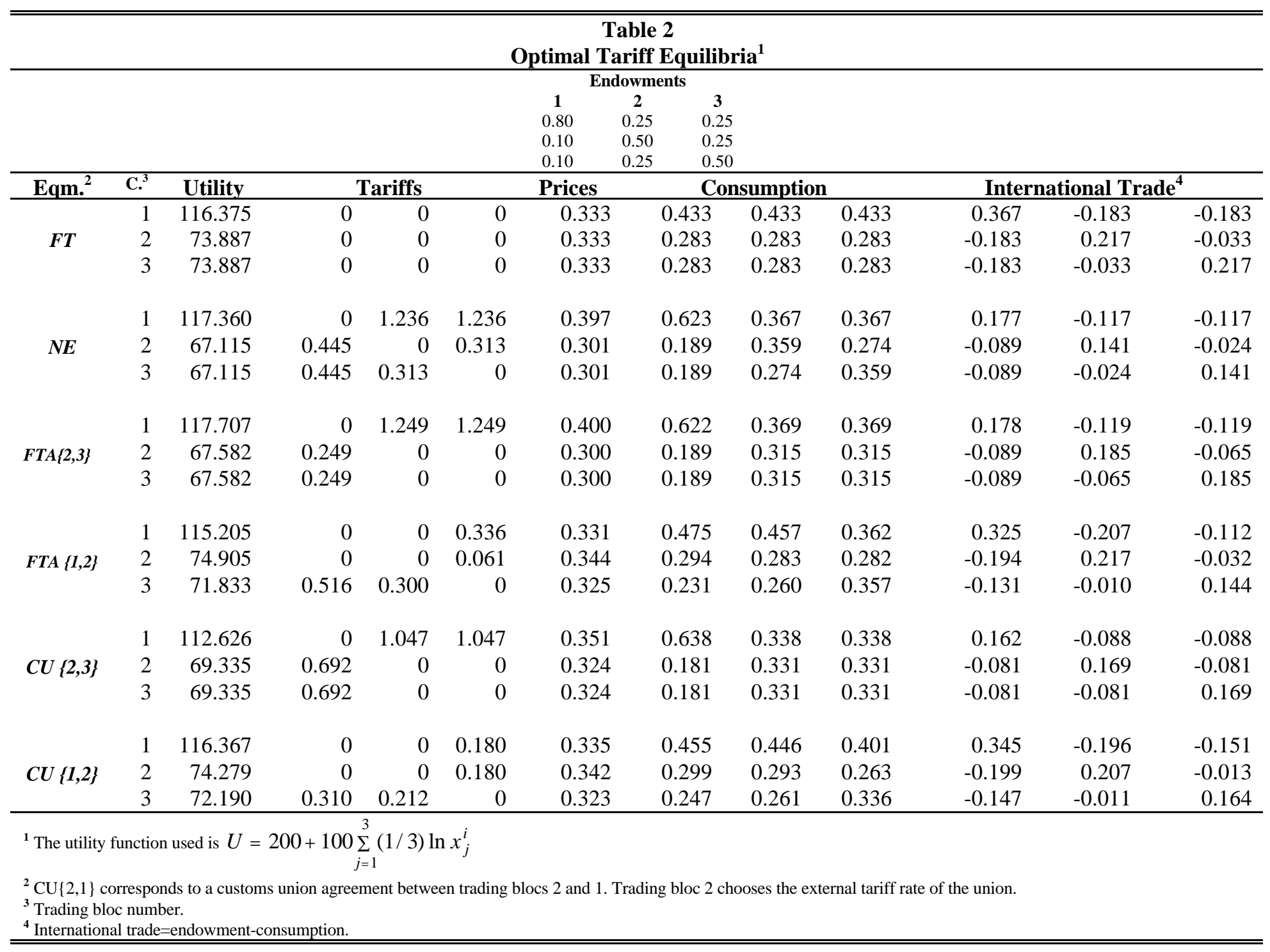




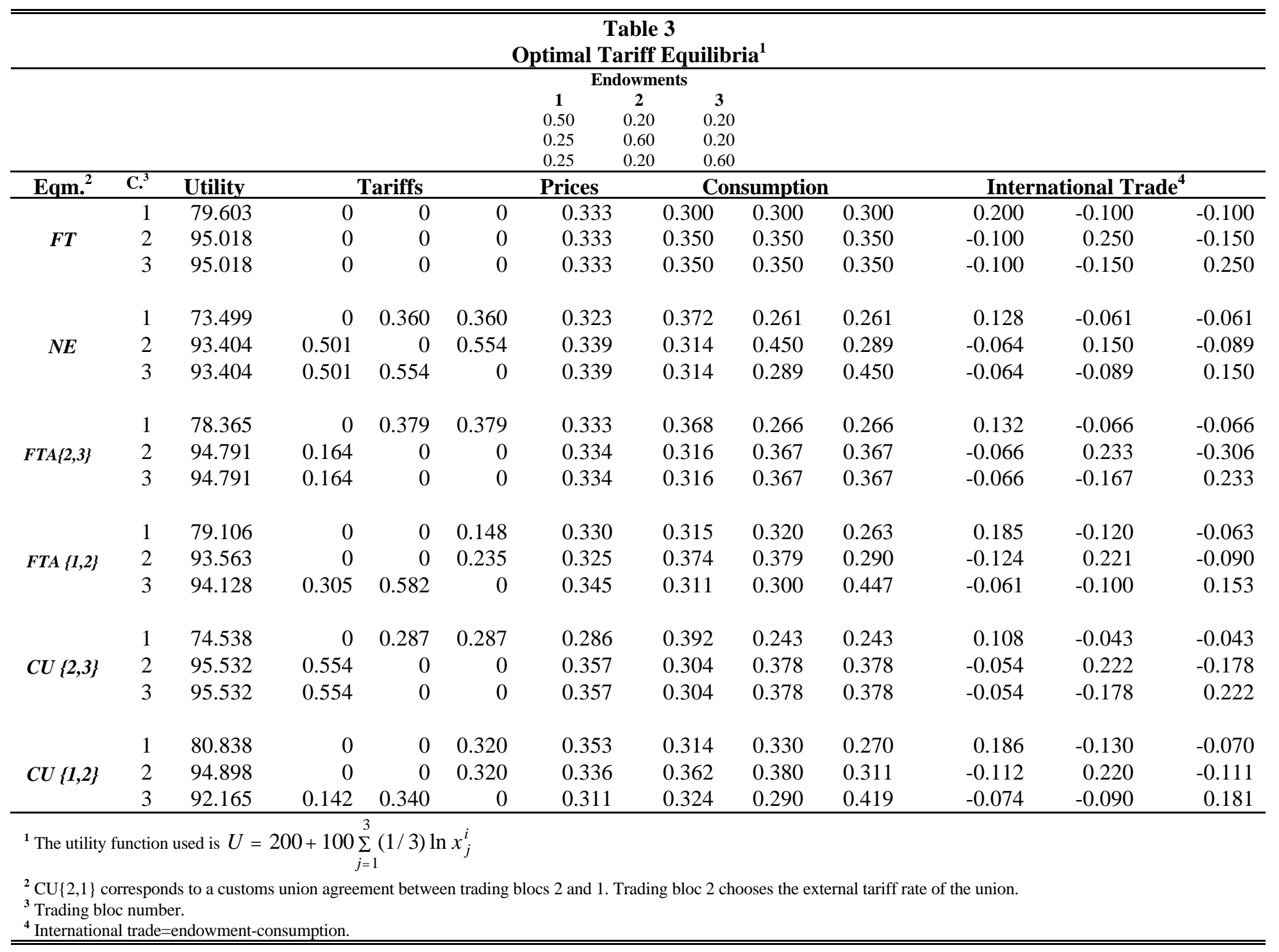


Table 4

Trading Blocs ${ }^{1}$

\begin{tabular}{llc}
\hline Trading Bloc & Members & Size \\
\hline 1 (Americas) & Canada, Mexico and the U.S. & $5.45 \mathrm{E}+9$ \\
2 (Europe) & France, Germany, Italy, Spain and England & $3.56 \mathrm{E}+9$ \\
3 (Asia) & China, Japan, and the South Korea & $3.56 \mathrm{E}+9$ \\
\hline${ }^{1}$ The data is taken from the Penn World Table 5.6 (1995), data set described in Summers and Heston (1991). \\
\hline \hline
\end{tabular}




\begin{tabular}{|c|c|c|c|c|c|}
\hline \multicolumn{6}{|c|}{$\begin{array}{c}\text { Table } 5 \\
\text { Welfare Cost of Trading Blocs } \\
\text { (Economy 1) } \\
\text { (in percent) } \\
\end{array}$} \\
\hline $\begin{array}{c}\text { Trade }^{1} \\
\text { Bloc }\end{array}$ & ne & $f t a\{23\}$ & $f t a\{12\}$ & $c u\{23\}$ & $\operatorname{cu}\{12\}$ \\
\hline 1 & -0.990 & -1.341 & 1.163 & 3.680 & 0.079 \\
\hline 2 & 6.548 & 6.110 & -1.023 & 4.449 & -0.549 \\
\hline 3 & 6.548 & 6.110 & 2.033 & 4.449 & 1.499 \\
\hline WORLD & 3.377 & 2.978 & 0.889 & 4.212 & 0.403 \\
\hline
\end{tabular}

\begin{tabular}{cccccc}
\hline \hline \multicolumn{6}{c}{$\begin{array}{c}\text { Table 6 } \\
\text { Welfare Cost of Trading Blocs } \\
\text { (Economy 2) } \\
\text { (in percent) }\end{array}$} \\
$\begin{array}{c}\text { Trade } \\
\text { Bloc }\end{array}$ & $\boldsymbol{n e}$ & fta $\{23\}$ & fta $\{12\}$ & $\boldsymbol{c u}\{\mathbf{2 3}\}$ & $\boldsymbol{c u}\{\mathbf{1 2}\}$ \\
\hline $\mathbf{1}$ & 2.082 & 1.230 & 0.496 & 4.939 & -1.192 \\
$\mathbf{2}$ & 1.600 & 0.227 & 1.444 & -0.515 & 0.073 \\
$\mathbf{3}$ & 1.600 & 0.227 & 0.886 & -0.515 & 2.803 \\
WORLD & 1.745 & 0.528 & 0.964 & 1.121 & 0.649 \\
\hline \hline
\end{tabular}

